\title{
Metal-organic frameworks as a very suitable reaction inductor for selective solvent-free multicomponent reaction: IRMOF-3 as a heterogeneous nanocatalyst for Kabachnik-Fields three-component reaction
}

\author{
Sadegh Rostamnia ${ }^{\mathrm{a}, *}$, Hongchuan Xin ${ }^{\mathrm{b}}$, Nasrin Nouruzi ${ }^{\mathrm{a}}$ \\ a Organic and Nano Group (ONG), Department of Chemistry, Faculty of Science, University of Maragheh, Maragheh, Iran \\ ${ }^{\mathrm{b}}$ Key Laboratory of Biofuels, Qingdao Institute of Bioenergy and Bioprocess Technology, Chinese Academy of Sciences, Qingdao 266101, China
}

\section{A R T I C L E I N F O}

Article history:

Received 7 February 2013

Received in revised form 25 April 2013

Accepted 10 May 2013

Available online 23 May 2013

Keywords:

Metal-organic framework

Porous coordination polymer

Nanocatalyst

Aminophosphonates

\section{A B S T R A C T}

IRMOF-3 is found to be an active, selective and stable solid catalyst for three-component, one-pot reaction of amines, aldehydes and dimethyl phosphite to form the corresponding $\alpha$-aminophosphonates in high yields. The catalyst can be isolated from the reaction mixture and reused at least four times.

(c) 2013 Elsevier Inc. All rights reserved.

\section{Introduction}

Metal-organic frameworks (MOFs) have been the focus of increasing attention during the past decade [1]. MOF-based structures demonstrate various advantages such as high surface areas, adjustable pore sizes, and the simplicity of processability, tunable, and stable alternative materials [2,3]. MOFs and functionalized- or modified-MOFs have been utilized as solid catalysts in FriedelCrafts alkylation and acylation [4], Sonogashira [5], alkene epoxidation [6], aldol [7], Suzuki [8], Biginelli [9], aza-Michael [10] and Knoevenagel $[11,12]$, condensation or reactions. Recently, unfunctionalized IRMOF-3 has been used as heterogeneous catalyst by Gascon et al. In their investigations, IRMOF-3 catalyst contain non-coordinated amino groups demonstrates that the basicity of the aniline-like amino group is enhanced when incorporated inside the pores of MOF channels [11]. Gascon et al., have also reported a thermal and chemical stable MIL-101(Al) material containing amine functional groups. Their $\mathrm{NH}_{2}$-MIL-101(Al) has shown a high activity in the basic catalyzed Knoevenagel condensation [12]. On the other hand, when Xamena and Corma have reexamined the catalytic properties of unfunctionalized IRMOF-3 for the Knoevenagel condensation, to aiming at determining the

\footnotetext{
* Corresponding author. Tel.: +98 421 2274893; fax: +98 $4212278001 x 108$.

E-mail addresses: rostamnia@maragheh.ac.ir, srostamnia@gmail.com (S. Rostamnia)
}

actual origin of the outstanding catalytic performance of IRMOF3 (Scheme 1), they found that besides the amino groups presented as responsible active sites in the Gascon report, the presence of structural defects and the presence of extra framework $\mathrm{ZnO}$ species can also contribute to the Knoevenagel reaction [13].

Organic-inorganic hybrid porous IRMOF-3 would make the materials hydrothermal stable and hydrophobic and thus provide the materials with improved catalytic properties during applications for organic small molecules [11-17]. For these reasons and in our continuing interest in the synthesis and application of the organic-inorganic hybrid nanoporous material in catalyst and multicomponent reactions fields [18-24], we report herein our results for the application and direct using of the unfunctionalized IRMOF-3 as an suitable, efficient and green catalyst for the threecomponent condensation (3-CRs) of an amine, aldehyde and phosphite without any solvent, salts and additives with excellent yields of biological and medicinal [25-27] interest $\alpha$-aminophosphonates (Scheme 1).

\section{Experimental}

\subsection{Preparation of IRMOF-3}

IRMOF-3 $\left(\mathrm{Zn}_{4} \mathrm{O}\left(\mathrm{H}_{2} \mathrm{~N}-\mathrm{TA}\right)_{3}\right)$ was synthesized according to the procedure from literature with slight modifications $[11,13]$. In a 


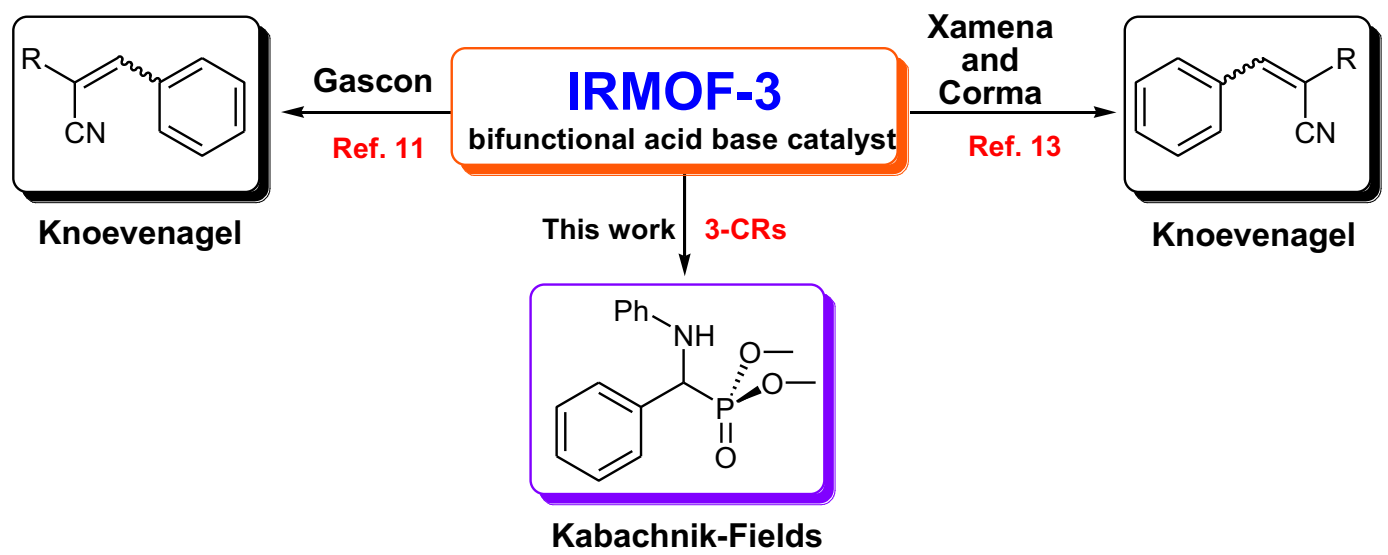

Scheme 1. Bifunctional acid base IRMOF-3 porous solid-catalyst.

typical catalyst preparation, $\mathrm{Zn}\left(\mathrm{NO}_{3}\right)_{2} \cdot 6 \mathrm{H}_{2} \mathrm{O}(12.5 \mathrm{mmol})$ and $\mathrm{H}_{2}$ ATA ( $4.1 \mathrm{mmol}$ ) were dissolved in $100 \mathrm{ml}$ DMF and stirred for 20 min at room temperature. The solution was transferred and sealed in a Teflon-lined autoclave, and kept at $100^{\circ} \mathrm{C}$ for $20 \mathrm{~h}$. The resulting brown solid was collected and washed with DMF and $\mathrm{CHCl}_{3}$, and the solid was finally dried in vacuum at $60^{\circ} \mathrm{C}$.

\subsection{General procedure for Kabachnik-Fields reaction}

A mixture of aldehydes ( $2.2 \mathrm{mmol})$, amines ( $2 \mathrm{mmol})$, dimethyl phosphite $(2 \mathrm{mmol})$ and MOF $(0.04 \mathrm{~g})$ under solvent free condition, was stirred at $40^{\circ} \mathrm{C}$ for $2 \mathrm{~h}$. After completion the reaction, as indicated by TLC, the reaction mixture was cooled to room temperature and $\mathrm{CH}_{2} \mathrm{Cl}_{2}$ was added. The catalyst was separated by filtration. The $\mathrm{CH}_{2} \mathrm{Cl}_{2}$ was evaporated.

Dimethyl phenyl(phenylamino)methylphosphonate (3a) ${ }^{1} \mathrm{H}$ NMR $\left(300.13 \mathrm{MHz}, \mathrm{CDCl}_{3}\right): 3.47\left(\mathrm{~d},{ }^{3} \mathrm{JP}_{\mathrm{HP}}=10.5,3 \mathrm{H}\right), 3.78$ (d, $\left.{ }^{3} J_{\mathrm{HP}}=10.5,3 \mathrm{H}\right), 4.84\left(\mathrm{~d},{ }^{2} J_{\mathrm{HP}}=24.3,1 \mathrm{H}\right), 5.02(\mathrm{br}, 1 \mathrm{NH}), 6.51-$ $7.51(\mathrm{~m}, 10 \mathrm{H})$.

Dimethyl (3-nitrophenyl)(phenylamino)methylphosphonate (3b) ${ }^{1} \mathrm{H}$ NMR $\left(300.13 \mathrm{MHz}, \mathrm{CDCl}_{3}\right): 3.64\left(\mathrm{~d},{ }^{3} J_{\mathrm{HP}}=10.8 \mathrm{~Hz}, 3 \mathrm{H}\right)$, $3.83\left(\mathrm{~d},{ }^{3} J_{\mathrm{HP}}=10.4,3 \mathrm{H}\right), 5.00\left(\mathrm{~d},{ }^{2} J_{\mathrm{HP}}=25.1,1 \mathrm{H}\right), 5.25(\mathrm{br}, 1$ $\mathrm{NH}), 6.62-8.41(\mathrm{~m}, 9 \mathrm{H})$.

Dimethyl (4-chlorophenyl)(phenylamino)methylphosphonate (3c) ${ }^{1} \mathrm{H}$ NMR (300.13 MHz, $\left.\mathrm{CDCl}_{3}\right): 3.55\left(\mathrm{~d},{ }^{3} J_{\mathrm{HP}}=10.8,3 \mathrm{H}\right), 3.77$ $\left(\mathrm{d},{ }^{3} J_{\mathrm{HP}}=10.8,3 \mathrm{H}\right), 4.52(\mathrm{br}, 1 \mathrm{NH}), 4.79\left(\mathrm{~d},{ }^{2} J_{\mathrm{HP}}=24.3,1 \mathrm{H}\right)$, 6.59-7.44 (m, $9 \mathrm{H})$.

Dimethyl ( $p$-tolylamino)(4-nitrophenyl)methylphosphonate (3d) ${ }^{1} \mathrm{H}$ NMR $\left(300.13 \mathrm{MHz}, \mathrm{CDCl}_{3}\right): 2.24(\mathrm{~m}, 3 \mathrm{H}), 3.50(\mathrm{~d}$, $\left.{ }^{3} J_{\mathrm{HP}}=10.5,3 \mathrm{H}\right), 3.78\left(\mathrm{~d},{ }^{3} J_{\mathrm{HP}}=10.5,3 \mathrm{H}\right), 4.80\left(\mathrm{~d},{ }^{2} J_{\mathrm{HP}}=24.3,1\right.$ $\mathrm{H}), 6.02(\mathrm{br}, 1 \mathrm{NH}), 6.54-7.38(\mathrm{~m}, 8 \mathrm{H})$.

Dimethyl (p-tolylamino)(2-methoxyphenyl)methylphosphonate $(3 e){ }^{1} \mathrm{H}$ NMR $\left(300.13 \mathrm{MHz}, \mathrm{CDCl}_{3}\right): 2.18(\mathrm{~m}, 3 \mathrm{H}), 3.45(\mathrm{~d}$, $\left.{ }^{3} J_{\mathrm{HP}}=10.5,3 \mathrm{H}\right), 3.82\left(\mathrm{~d},{ }^{3} \mathrm{JHP}_{\mathrm{HP}}=10.5,3 \mathrm{H}\right), 3.93(\mathrm{~s}, 3 \mathrm{H}), 4.06(\mathrm{br}, 1$ $\mathrm{NH}), 5.43\left(\mathrm{~d},{ }^{2} \mathrm{~J}_{\mathrm{HP}}=24.0,1 \mathrm{H}\right), 6.54-7.49(\mathrm{~m}, 8 \mathrm{H})$.

Dimethyl (p-tolylamino)(2-chlorophenyl)methylphosphonate (3f) ${ }^{1} \mathrm{H}$ NMR $\left(300.13 \mathrm{MHz}, \mathrm{CDCl}_{3}\right): 2.16(\mathrm{~m}, 3 \mathrm{H}), 3.43(\mathrm{~d}$, $\left.{ }^{3} J_{\mathrm{HP}}=9.9,3 \mathrm{H}\right), 3.83\left(\mathrm{~d},{ }^{3} J_{\mathrm{HP}}=9.9,3 \mathrm{H}\right), 4.85(\mathrm{br}, 1 \mathrm{NH}), 5.39(\mathrm{~d}$, $\left.{ }^{2} J_{\mathrm{HP}}=24.9,1 \mathrm{H}\right), 6.49-7.56(\mathrm{~m}, 8 \mathrm{H})$.

Dimethyl (2-methoxyphenyl)(pyrrolidin-1-yl)methylphosphonate $(3 g){ }^{1} \mathrm{H}$ NMR $\left(300.13 \mathrm{MHz}, \mathrm{CDCl}_{3}\right): 1.69(\mathrm{~m}, 4 \mathrm{H}), 2.16(\mathrm{~m}, 2$ $\mathrm{H}), 2.64(\mathrm{~m}, 2 \mathrm{H}), 3.46\left(\mathrm{~d},{ }^{3} J_{\mathrm{HP}}=6.3 \mathrm{~Hz}, 3 \mathrm{H}\right), 3.77\left(\mathrm{~d},{ }^{3} J_{\mathrm{HP}}=6.3 \mathrm{~Hz}\right.$, $3 \mathrm{H}), 3.85(\mathrm{~s}, 3 \mathrm{H}), 4.66\left(\mathrm{~d},{ }^{2} J_{\mathrm{HP}}=18.0 \mathrm{~Hz}, 1 \mathrm{H}\right), 6.89-7.75(\mathrm{~m}, 4 \mathrm{H})$.

Dimethyl (N,N-diethylamino)(3-nitrophenyl)methylphosphonate (3h) ${ }^{1} \mathrm{H} \mathrm{NMR}\left(300.13 \mathrm{MHz}, \mathrm{CDCl}_{3}\right): 0.95\left(\mathrm{t},{ }^{3} \mathrm{~J}_{\mathrm{HH}}=7.2 \mathrm{~Hz}, 6 \mathrm{H}\right)$, $2.21(\mathrm{~m}, 2 \mathrm{H}), 2.88(\mathrm{~m}, 2 \mathrm{H}), 3.37\left(\mathrm{~d},{ }^{3} \mathrm{HP}_{\mathrm{HP}}=9.3 \mathrm{~Hz}, 3 \mathrm{H}\right), 3.77(\mathrm{~d}$, $\left.{ }^{3} J_{\mathrm{HP}}=9.3 \mathrm{~Hz}, 3 \mathrm{H}\right), 4.12\left(\mathrm{~d},{ }^{2} J_{\mathrm{HP}}=24.9 \mathrm{~Hz}, 1 \mathrm{H}\right), 7.17-7.38(\mathrm{~m}, 5 \mathrm{H})$.
Dimethyl 1-(phenylamino)cyclohexylphosphonate (3i) ${ }^{1} \mathrm{H}$ NMR (300.13 MHz, $\mathrm{CDCl}_{3}$ ): 1.13-2.13 (m, $\left.10 \mathrm{H}\right), 3.45$ (br, $\left.1 \mathrm{NH}\right), 3.55$ (d, $\left.{ }^{3} J_{\mathrm{HP}}=10.5 \mathrm{~Hz}, 6 \mathrm{H}\right), 6.66-7.06(\mathrm{~m}, 5 \mathrm{H})$.

\section{Results and discussion}

\subsection{Catalyst synthesis and characterization}

The nanoporous metal-organic framework IRMOF-3 was prepared by refluxing of 2-aminoterephthalic acid $\left(\mathrm{H}_{2} \mathrm{ATA}\right)$ and zinc nitrate hexahydrate in DMF by a solvothermal method, according to a literature procedure $[11,13]$. In a typical catalyst preparation, $\mathrm{Zn}\left(\mathrm{NO}_{3}\right)_{2} \cdot 6 \mathrm{H}_{2} \mathrm{O}(3.75 \mathrm{~g})$ and $\mathrm{H}_{2} \mathrm{ATA}(0.75 \mathrm{~g})$ were dissolved in $100 \mathrm{ml} \mathrm{N}, \mathrm{N}$-dimethylformamide (DMF) and the mixture was transferred to Teflon-lined autoclave. The mixture of the reaction kept for $1 \mathrm{~h}$ at $25^{\circ} \mathrm{C}$ and then at $100{ }^{\circ} \mathrm{C}$ for $17 \mathrm{~h}$. The resulting brown solid was collected and washed thrice with $\mathrm{CHCl}_{3}$, and the solid was finally dried in vacuum at $60^{\circ} \mathrm{C}$. The IRMOF- 3 structure is made of $\mathrm{Zn}_{4} \mathrm{O}$ tetranuclear clusters connected by rigid $\mathrm{NH}_{2}$-benzenedicarboxylic linkers to generate a cubic framework (Fig. 1).

The IRMOF-3 was then characterized using a variety of different techniques. The IR spectra of IRMOF-3 show two peaks in 3470 and $3359 \mathrm{~cm}^{-1}$ due to the existence of the amino groups of the $\mathrm{NH}_{2}-\mathrm{TA}$ ligand [24]. The two sharp bands at 1575 and $1385 \mathrm{~cm}^{-1}$ corresponds to asymmetric $\left(v_{\mathrm{as}}(\mathrm{C}-\mathrm{O})\right)$ and symmetric $\left(v_{\mathrm{s}}(\mathrm{C}-\mathrm{O})\right)$ vibrations of carboxyl groups, respectively [25]. And the peaks centered at 1656,1496 , and $1421 \mathrm{~cm}^{-1}$ was ascribed to $\mathrm{C}=\mathrm{C}$ stretching vibration of the aromatic. The $1257 \mathrm{~cm}^{-1}$ frequency can be assigned to $\mathrm{C}-\mathrm{N}$ vibrations. Diffraction peaks at around $2 \theta=6.8^{\circ}$ and $9.6^{\circ}$ are readily recognized from the XRD pattern (Fig. 2d). The observed diffraction peaks agree with the IRMOF-3

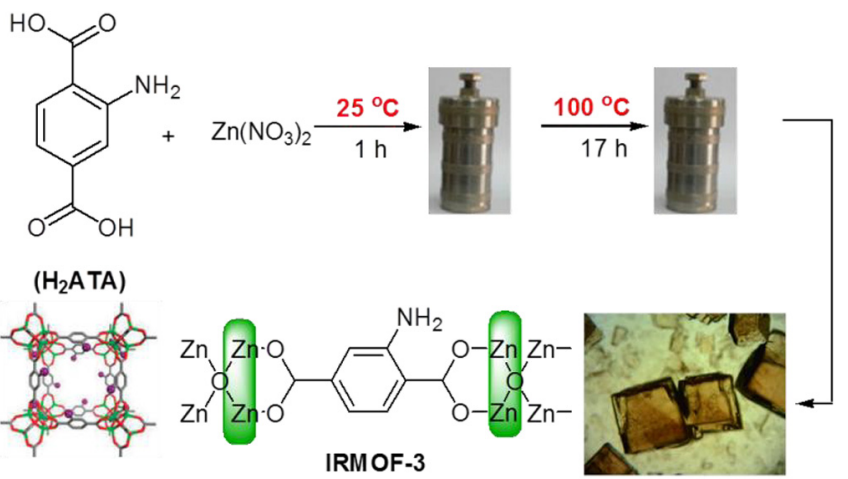

Fig. 1. Preparation process of unfunctionalized IRMOF-3. 

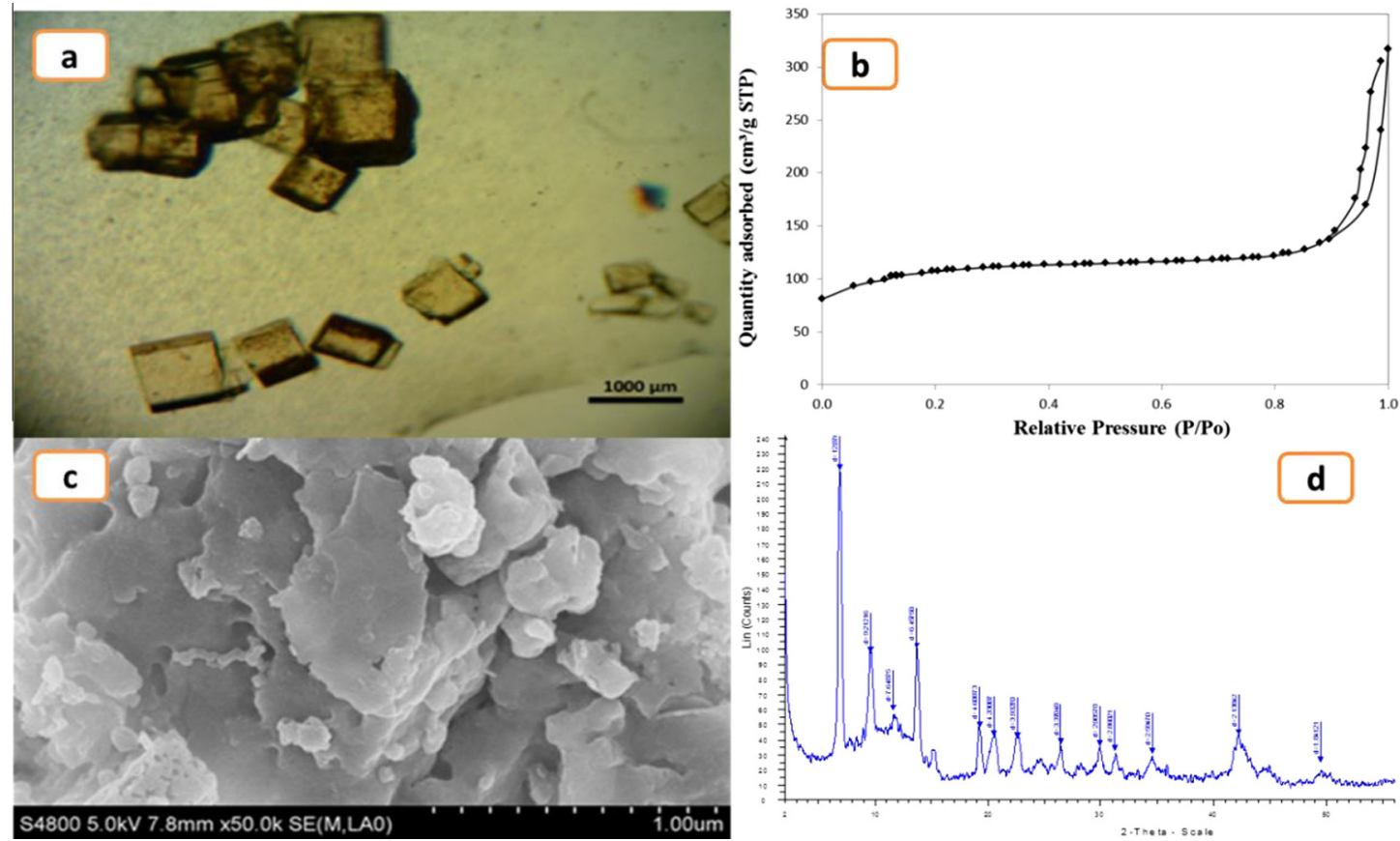

Fig. 2. (a) Optical microscope photograph of IRMOF-3, (b) The nitrogen adsorption-desorption isotherms at $77 \mathrm{~K}$ of IRMOF-3, (c) SEM images and (d) X-ray diffraction patterns of IRMOF-3.

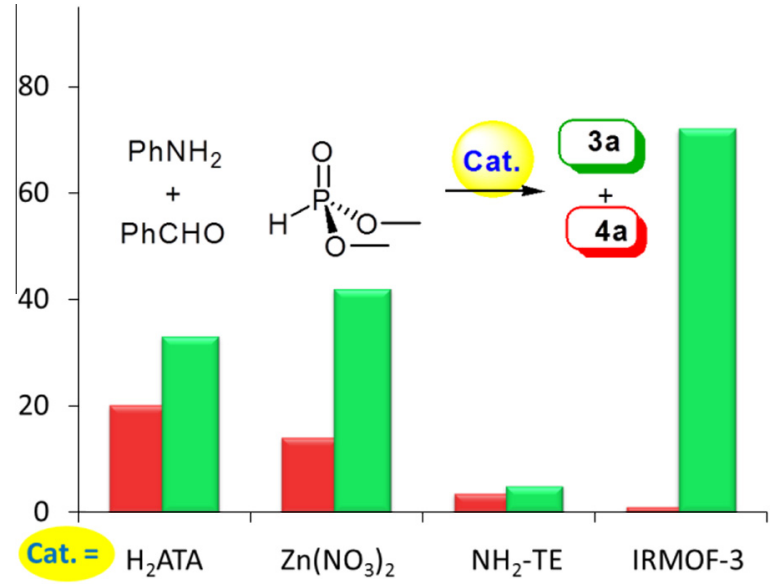

Fig. 3. Reaction scale: aniline $(2 \mathrm{mmol})$, benzaldehyde $(2.2 \mathrm{mmol})$, dimethyl phosphite $(2 \mathrm{mmol}$ ) and catalysts $(4 \mathrm{~mol} \%)$ in $3 \mathrm{~mL} \mathrm{MeCN}$. Aminophosphonate 3a (green) and hydroxy phosphonate $\mathbf{4 a}$ (red). (For interpretation of the references to color in this figure legend, the reader is referred to the web version of this article.)

[11]. The crystal structure of IRMOF-3 seems changed to amorphous through the reusing after 4 times (see SI).

The nitrogen adsorption-desorption isotherms of the solvothermal synthesized IRMOF-3 are displayed in Fig. 2b. The optical microscope photograph and SEM images (Fig. 2a and c), together
Table 1

Study of the solvent and temperature on the model reaction. ${ }^{\text {a }}$

\begin{tabular}{llll}
\hline Solvent & Temp $\left({ }^{\circ} \mathrm{C}\right)$ & Time $(\mathrm{h})$ & Yield\% 3a \\
\hline THF & 60 & 4 & 93 \\
$\mathrm{CH}_{3} \mathrm{CN}$ & 60 & 2 & 72 \\
$\mathrm{CH}_{3} \mathrm{CN}$ & r.t & 2 & 40 \\
Toluene & 60 & 4 & 90 \\
Solvent-free & 60 & 2 & 94 \\
Solvent-free & 40 & 2 & 91 \\
Solvent-free & r.t. & 3 & 87 \\
\hline
\end{tabular}

${ }^{a}$ Reaction scale: aniline ( $\left.2 \mathrm{mmol}\right)$, benzaldehyde $(2.2 \mathrm{mmol})$, dimethyl phosphite ( $2 \mathrm{mmol}$ ) and catalysts ( $4 \mathrm{~mol} \%)$ in $3 \mathrm{~mL}$ solvent.

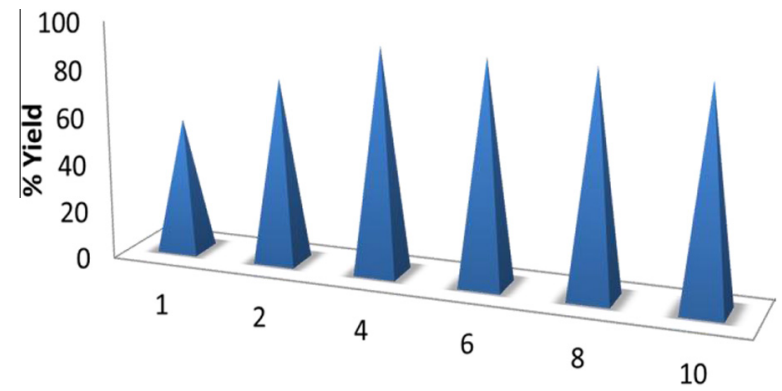

Fig. 4. Catalyst amounts study of IRMOF-3 in synthesis of $\mathbf{3 a}$.

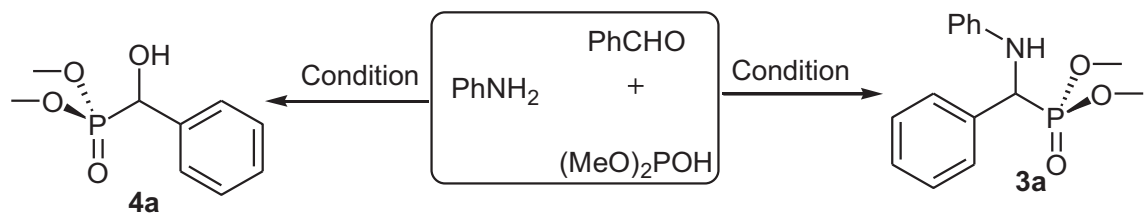

Scheme 2. Expected products from the reaction of dimethyl phosphite, amines and aldehydes. 
Table 2

Synthesis of $\alpha$-amino phosphonates.

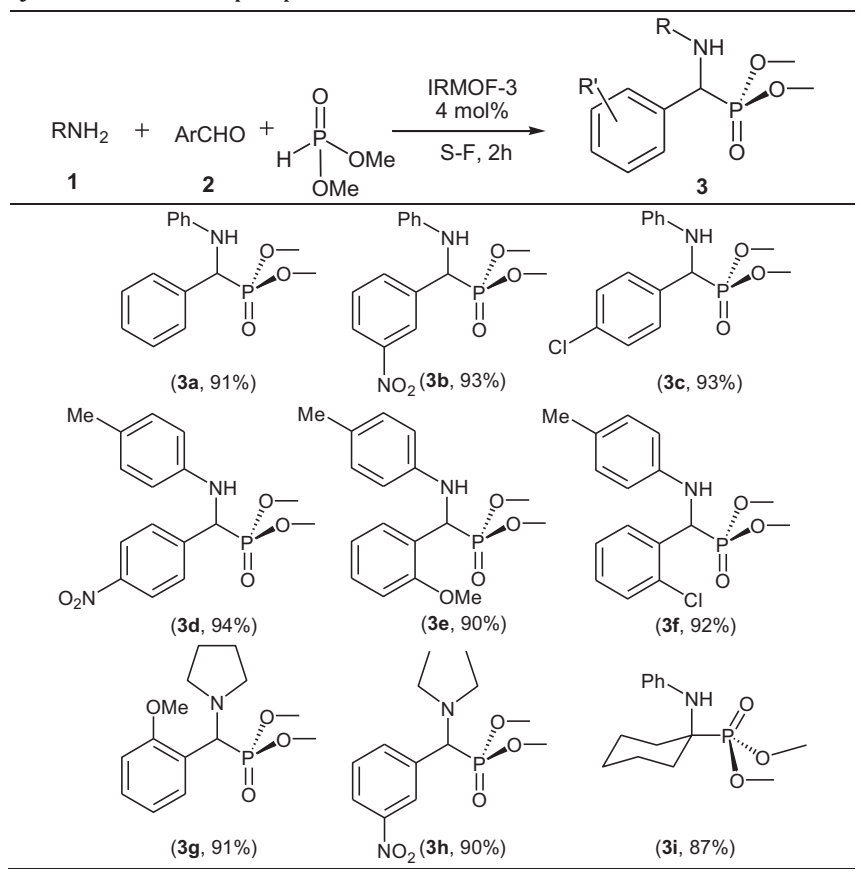

with the XRD patterns showed that the IRMOF-3 was highly crystalline.

\subsection{Catalytic studies}

As expected, in which adduct of amines and aldehydes was treated with phosphites under the reaction conditions [25-27], led to the products $\alpha$-aminophosphonates 3, and $\alpha$-hydroxy phosphonates 4 (Scheme 2). For our study, aniline, benzaldehyde and dimethyl phosphite were chosen as the benchmark substrates in the model reaction.

Due to the fact that the nature of the IRMOF-3 nanoreactor or its synthetic component may play an important role in the synthesis of aminophosphonate $\mathbf{3 a}$, and based on our previous experience about porous nanoreactor in organic process, the initial reaction was carried out using $4 \mathrm{~mol} \% \mathrm{H}_{2} \mathrm{ATA}, \mathrm{Zn}\left(\mathrm{NO}_{3}\right)_{2}$, 2-aminoterephthalic ester $\left(\mathrm{NH}_{2}\right.$-TE) and IRMOF-3 catalyst at $60{ }^{\circ} \mathrm{C}$ for $2 \mathrm{~h}$ in acetonitrile. The IRMOF-3 was assessed for its catalytic activity in the Kabachnik-Fields by studying the model reaction to produce of $\alpha$-aminophosphonate 3a as the principal product and $\alpha$-hydroxy phosphonate $\mathbf{4 a}$ as the by-product (Fig. 3 ). When the model reaction was run using IRMOF-3, the product 3a was obtained $72 \%$ yield and 4a was not observed.

The model reaction was screened in polar and nonpolar solvents using $4 \% \mathrm{~mol}$ of IRMOF-3. When the reaction was run under solvent-free condition, the product was obtained in $91 \%$ yield at $40{ }^{\circ} \mathrm{C}$ in $2 \mathrm{~h}$ (Table 1 ).

The model reaction was carried out using different amounts of IRMOF-3 nanoreactor as the catalyst (Fig. 4). A high yield of $\alpha$ aminophosphonate 3a (91\%) was obtained with $4 \mathrm{~mol} \%$ of the catalyst. A further increase in the amount of catalyst (6-10 mol\%) did not have any significant effect on the product yield or reaction time.

In order to examine the scope of this process, and to demonstrate the diversity of the IRMOF-3, the optimized conditions were applied to a series of substrate as shown in Table 2 .

In a comparative study to show the chemoselectivity, dimethyl phosphite was treated with the mixture of aniline, benzaldehyde and cyclohexanone. Analysis of the mixture after $2 \mathrm{~h}$ shows that only benzaldehyde reacted with aniline to corresponds $\mathbf{3 a}$ (Scheme 3).

The possibility of recycling and reusing the catalyst was then examined. In this case, after completion of the reactions (TLC), hot ethanol or $\mathrm{CH}_{2} \mathrm{Cl}_{2}$ was added and the catalyst was filtered and reused for four times (Fig. 5).

To the best of our knowledge, our results also show that the catalytic activity and selectivity of IRMOF-3 are higher than porous $\mathrm{SBA}-15 / \mathrm{SO}_{3} \mathrm{H}$ (model reaction). When the model reaction was performed in the presence of the SBA-15 sulfonic acid, although benzaldehyde was almost consumed soon, but a mixture of $\mathbf{3 a}$ and $\mathbf{4 a}$ was formed [28].

In summary, we reported Kabachnik-Fields three-component coupling of amines, aldehydes, and dimethyl phosphite to produce pharmacy and biological interest $\alpha$-aminophosphonates catalyzed by IRMOF-3, in high yields under solvent-free conditions. This method has many advantages such as short reaction time, small amount of catalyst used and facilely recycled, especially the abstaining from toxic organic solvents in the reaction, which provides a green and effective method for synthesis of $\alpha$-aminophosphonates.

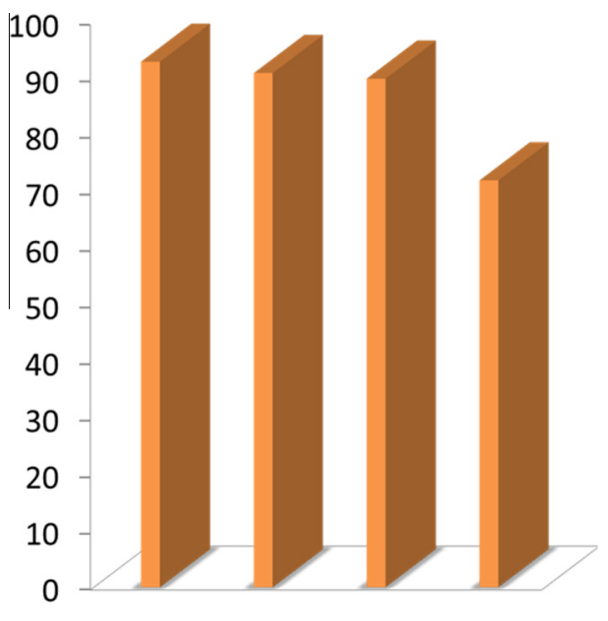

Fig. 5. Recyclability of MOF on the synthesis of $\mathbf{3 a}$.

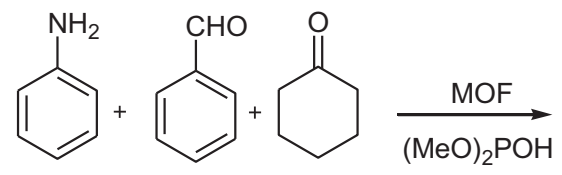<smiles>COP(=O)(OC)C(N)c1ccccc1</smiles>

$(3 a, 86 \%)$<smiles>COP(=O)(OC)C1(N)CCCCC1</smiles>

(3i, trace)

Scheme 3. Chemoselective addition of phosphite to aldehyde and ketone. 


\section{Acknowledgment}

The authors thank the referees for their valuable comments.

\section{Appendix A. Supplementary data}

Supplementary data associated with this article can be found, in the online version, at http://dx.doi.org/10.1016/j.micromeso.2013. 05.009.

\section{References}

[1] H. Li, M. Eddaoudi, M. O’Keeffe, O.M. Yaghi, Nature 402 (1999) 276-279.

[2] J.L.C. Rowsell, O.M. Yaghi, Microporous Mesoporous Mater. 73 (2004) 3-14.

[3] Z.Q. Li, L.G. Qiu, T. Xu, Y. Wu, W. Wang, Z.Y. Wu, X. Jiang, Mater. Lett. 63 (2009) 78-80.

[4] N.T.S. Phan, K.K.A. Le, T.D. Phan, Appl. Catal., A 382 (2010) 246-253.

[5] S. Gao, N. Zhao, M. Shu, S. Che, Appl. Catal., A 388 (2010) 196-201.

[6] F. Song, C. Wang, J.M. Falkowski, L. Ma, W. Lin, J. Am. Chem. Soc. 132 (2010) 15390-15398

[7] T. Dewa, T. Saiki, Y. Aoyama, J. Am. Chem. Soc. 123 (2001) 502-503.

[8] F.X.L.I. Xamena, A. Abad, A. Corma, H. Garcia, J. Catal. 250 (2007) 294-298.

[9] P. Li, S. Regati, R.J. Butcher, H.D. Arman, Z. Chen, S. Xiang, B. Chen, C.G. Zhao, Tetrahedron Lett. 52 (2011) 6220-6222.

[10] M. Savonnet, S. Aguado, U. Ravon, D. Bazer-Bachi, V. Lecocq, N. Bats, C. Pinel, D. Farrusseng, Green Chem. 11 (2009) 1729-1732.
[11] J. Gascon, U. Aktay, M.D. Hernandez-Alonso, G.P.M. van Klink, F. Kapteijn, J. Catal. 261 (2009) 75-87.

[12] P. Serra-Crespo, E.V. Ramos-Fernandez, J. Gascon, F. Kapteijn, Chem. Mater. 23 (2011) 2565-2572.

[13] F.X.L. Xamena, F.G. Cirujano, A. Corma, Microporous Mesoporous Mater. 157 (2012) 112-117.

[14] J.L.C. Rowsell, O.M. Yaghi, J. Am. Chem. Soc. 128 (2006) 1304-1315

[15] K.K. Tanabe, Z. Wang, S.M. Cohen, J. Am. Chem. Soc. 130 (2008) 8508-8517.

[16] Z.Q. Wang, S.M. Cohen, J. Am. Chem. Soc. 129 (2007) 12368-12369.

[17] M.J. Ingleson, J.P. Barrio, J.B. Guilbaud, Y.Z. Khimyak, M.J. Rosseinsky, Chem. Commun. (2008) 2680-2682.

[18] S. Rostamnia, K. Lamei, M. Mohammadquli, M. Sheykhan, A. Heydari, Tetrahedron Lett. 53 (2012) 5257-5260.

[19] S. Rostamnia, K. Lamei, Synthesis (2011) 3080-3082.

[20] H. Xin, J. Zhao, X. Xu, J. Li, W. Zhang, X. Guo, E.M. Hensen, Q. Yang, C. Li, J. Phys. Chem. C 114 (2010) 6553-6559.

[21] H. Xin, A. Koekkoek, Q. Yang, R. Santen, Can Li, E. Hensen, Chem. Commun. (2009) 7590-7592.

[22] S. Rostamnia, A. Zabardasti, J. Fluorine, Chem. 144 (2012) 69-72.

[23] S. Rostamnia, A. Alizadeh, L.G. Zhu, J. Comb. Chem. 143 (2009) 143-145.

[24] H. Xin, J. Liu, F. Fan, Z. Feng, G. Jia, Q. Yang, C. Li, Microporous Mesoporous Mater. 113 (2008) 231-239.

[25] M.C. Allen, W. Fuher, B. Tuck, R. Wade, J.M. Wood, J. Med. Chem. 32 (1989) $1652-1661$.

[26] G.F. Makhaeva, V.V. Malygin, A.Y. Aksinenko, V.B. Sokolov, N.N. Strakhova, A.N. Rasdolsky, R.J. Richardson, I.V. Martynov, Biochem. Biophys. 400 (2005) 92-95.

[27] M.J. Bloemink, J.J.H. Diederen, J.P. Dorenbos, R.J. Heetebrij, B.K. Keppler, J. Reedijk, Eur. J. Inorg. Chem. 10 (1999) 1655-1657.

[28] S. Rostamnia, H. Xin, X. Liu, K. Lamei, J. Mol. Catal. A: Chem. 2013, Available from: http://dx.doi.org/10.1016/j.molcata.2013.03.017. 